\title{
Выращивание двурядника тонколистного в открытом грунте
}

\begin{abstract}
А.В. Литнецкий, М.И. Иванова, А.И. Кашлева, Д.Н. Балеев, А.Ф. Бухаров, В.В. Михайлов, Н.Л. Девочкина

Представлена технология выращивания двурядника тонколистного на примере ООО «Феличита», специализирующаяся на его промышленном выращивании в средней полосе России. В Московской области в открытом грунте семена высевают с мая до середины августа, в Тульской области - с конца апреля до конца августа с интервалом 7 суток. Продуктивность колеблется от 1,9 до 8,4 г/растение, урожайность - от 0,5 до 1,8 т/га за каждый цикл выращивания, общая урожайность превышает 35 т/га.

Ключевые слова: двурядник тонколистный, Diplotaxis tenuifolia (L.) D.C., агротехнология, урожайность, открытый грунт.
\end{abstract}

Д вурядник тонколистный интродуцирован из дикого вида в коммерческую культуру около двадцати пяти лет назад. Он привлекает внимание благодаря своей пластичности, высокой урожайности и рентабельности. В последнее десятилетие экономический интерес к производству двурядника тонколистного, известного как рукола, возрос из-за высокой популярности готовых к употреблению салатов-миксов, так называемых «овощей четвертого поколения» - коммерческий продукт, который сохраняет свежесть и характерный аромат листьев, тем самым продлевая срок их хранения и доступность на рынке $[1,2]$. Благодаря более гладким и хрустящим листьям, двурядник тонколистный распространился в большинстве с.-х. районов Италии, занимая площадь около 4000 га [3, 4]. В нашей стране лишь единичные фермеры занима-

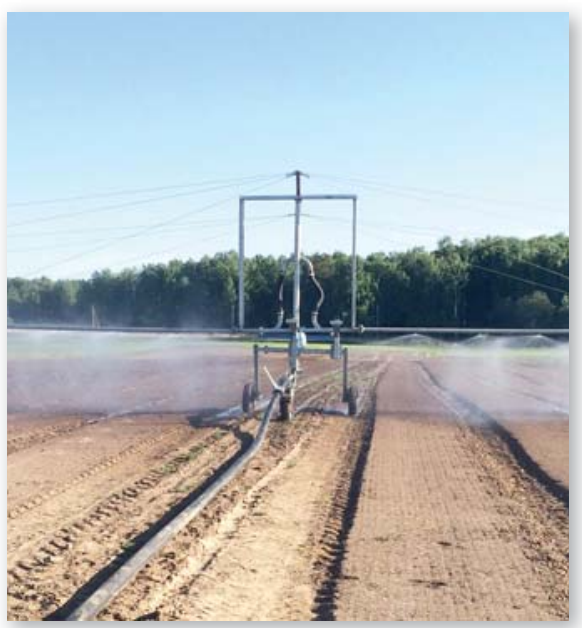

Полив посевов двурядника тонколистного ются промышленным производством этой культуры в открытом грунте, а в салатных линиях [5].

Двурядник тонколистный содержит больше сухого вещества (90 г/кг) и волокна (9 г/кг), чем другие салатные растения, но не отличается по содержанию питательных веществ в пересчете на свежую массу: калия (4,7 г/кг свежей массы), кальция $(3,1$ г/кг) и железа (52 мг/кг). Содержание общего фенола в растительном экстракте - 2,9 г/кг [6], каротиноидов - 129 мг/кг, аскорбиновой кислоты - 90 мг/кг [3]. Листья характеризуются горьким или острым вкусом, обусловленным содержанием глюкозинолатов, и сильным ароматом, в зависимости от выделяемых летучих изотиоцианатов [7]. Диетологи рекомендуют включать в рацион двурядник тонколистный для профилактики сердечно-сосудистых и онкологических заболеваний, снижения веса.

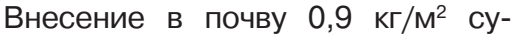
хих остатков двурядника тонколистного в качестве биофумиганта значительно снижает выживаемость популяции Fusarium oxysporum f. sp. radicilycopersici, Macophomina phaseolina и Rhizoctonia solani, тогда как подавление корневой нематоды Meloidogyne javanica отмечается только тогда, когда этот прием связан с соляризацией [8].

Цель статьи: представить аспекты технологии двурядника тонколистного на примере ООО «Феличита», специализирующейся на промышленной технологии выращивания данной культуры в средней полосе России на площади 10 га. защищенном грунте выращивают на
Двурядник тонколистный выращивают в открытом грунте как baby leaf - сеянцы зеленных овощных культур, убираемые в фазу 2-3 настоящих листьев высотой не более 10 см. Посев семян производят в открытый грунт, тогда как для пучковой продукции выращивают через рассаду.

Перед посевом - вспашка на глубину 25 см, за которой следует боронование. Формирование и выравнивание поверхности гребней проводят до или одновременно с посевом. Перед посевом гряды формируют фрезой-грядоформирователем AF 160 Super (Hortech, Италия), одновременно вносят азофоску (16:16:16) из расчета 500 кг/га. Полезно практиковать применение зеленого удобрения и соблюдать севооборот с учетом того, что двурядник тонколистный может аллелопатически влиять на растения из семейств мотыльковых, луковых, тыквенных и пасленовых.

В Московской области в открытом грунте семена высевают с мая до середины августа, в Тульской области - с конца апреля до конца августа интервалом 7 дней. Посев семян проводят специализированной сеялкой СM 2000 (Bassi Seminatrici, Италия). Гряда шириной 130 см, 24 строки. Расстояние между строчками 5 см, между растениями в строчке 5-7 см. Глубина заделки семян 0,20,3 см. Норму высева устанавливают из расчета 2,6-3,7 млн. шт/га растений. Всходы появляются в среднем через четверо суток после посева, в зависимости от периода посева, на легких почвах необходимо уплотнение. Для облегчения механизированного сбора урожая необходимо выравнивание поверхности почвы.

При выращивании на пучковую продукцию гряды мульчируют черной полиэтиленовой или биоразлагаемой пленкой, позволяющей сократить цикл выращивания, улучшить контроль сорняков и вредителей, а также качество продукции. Под мульчей капельные трубы размещают в чередующиеся ряды. Выращенную в кассетах рассаду в течение 20-30 суток (15-25 семян на ячейку) выса- 


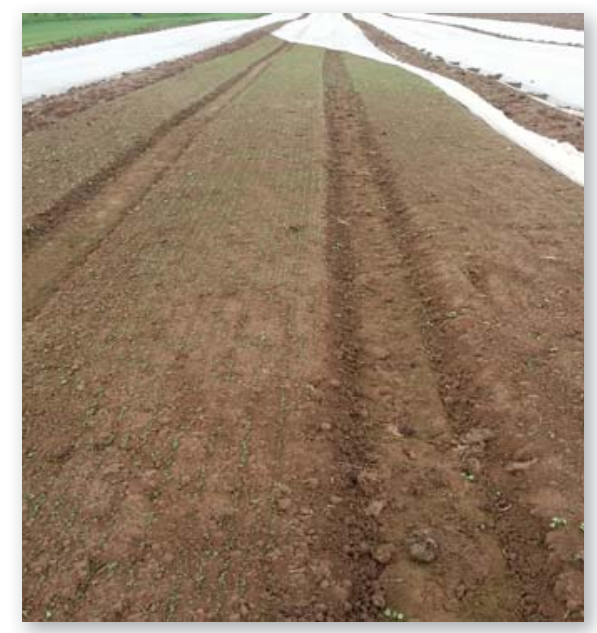

Всходы двурядника тонколистного

живают с расстоянием между рядами 10-15 см, густота - от 500 до 1250 шт/м². Монокультура, а также как фасоль, сельдерейные, тыквенные и пасленовые как предшественники не рекомендуются.

Крестоцветные блошки повреждают листья. Использование пестицидов весьма проблематично из-за очень короткого цикла производства, соображений экологической безопасности продукции. Инсектициды из класса пиретроидов эффективны в отношении тлей, блошек и др. Однако их неизбирательное действие способствует распространению вторичных вредителей, таких, как клещи. В последнее время в Европе для комплексного управления вредителями на двуряднике тонколистном используют препараты из несколько химических классов с различными механизмами действия. Большинство этих инсектицидов характеризуются коротким ин-

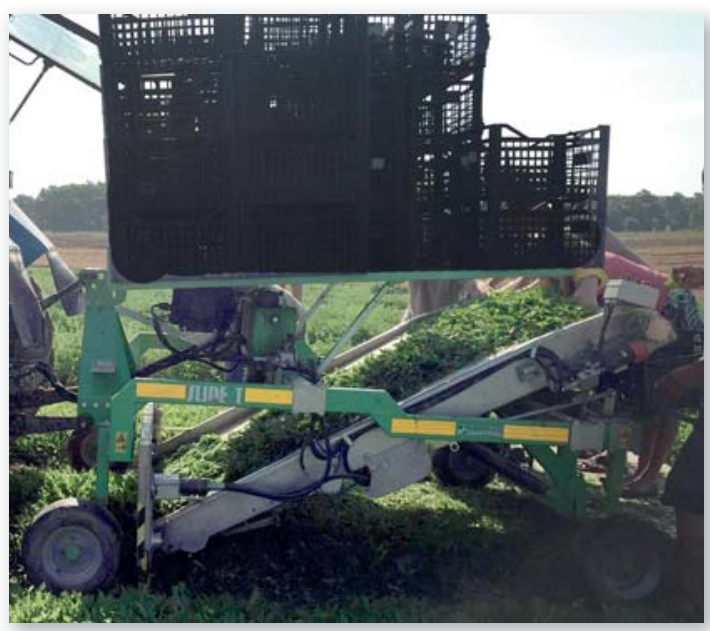

Срезка зелени двурядника тонколистного тервалом безопасности (3-7 дней). Химические инсектициды можно использовать совместно с препаратам природного происхождения, такими, как азадирахтин, который эффективен против личинок тлей, гусениц бабочек и крестоцветных блошек.

Препараты на основе Bacillus thuringiensis эффективны против личинок бабочек и селективны для их естественных врагов, таких, как паразитоиды Angitia tibialis и Apanteles spp., которые, как агенты биологического контроля, могут способствовать управлению Plutella xylostella. Слизни (например, Deroceras reticulatum, Arion spp.) также вредны, приманки с метальдегидом обычно эффективны против них.

В средней полосе России период вегетации (от всходов до готовой продукции: листовая пластинка длиной 10 см) составляет 30 суток. Вторая срезка - через 10 суток после первой. В течение вегетации дважды проводят некорневую подкормку монокалием фосфата (норма 2-4 кг/га).

Двурядник тонколистный со 100 кг урожая выносит 0,28 кг азота, 0,11 кг фосфора и 0,34 кг калия, и подкормку необходимо проводить с учетом физических и химических свойств почвы. Питательные вещества, требуемые растениями, можно также давать через фертигацию, а питательный раствор должен

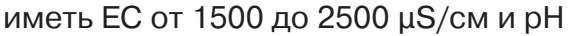
от 6,0 до 6,5. Соотношение между N, $\mathrm{P}_{2} \mathrm{O}_{5}$ и $\mathrm{K}_{2} \mathrm{O}$ изменяется в соответствии с фазой роста и развития растений: 1,5:0,5:1,0 от посева или высадки рассады до первой срезки и 2,0:0,5:1,5 после каждой последующей срезки. В весенне-летних посевах в открытом грунте дозы азота никогда не должны превышать 100 кг/ га; однако, когда в защищенном грунте на песчаной почве планируется 3-5 сборов урожая, дозы могут быть удвоены. Промежуток времени между посевом и сбором урожая у двурядника тонколистного короткий, и, кроме того, его листья склонны накапливать большое количество нитрата даже до 10 г/кг свежей массы из-за довольно низкой эффективности использования азота растениями. Виды растений, произрастающих на Пиренейском полуострове, эволюционировали при низком содержании питательных веществ в почве. Кроме того, чрезмерный азот ухудшает качество продукции во время хранения, поэтому следует строго избегать вносить его ближе к уборке. Тем не менее, выход и качество продукции во многом зависит от взаимодействия доступного азота с почвенной влагой, а эффективность использования азота выше при 60 кг/га, а не 120 кг/га, хотя последняя доза приводит к увеличению урожая на $13 \%$.

Двурядник тонколистный приспособлен к суровым и засушливым почвам, а хорошо развитая корневая система, достигающая до $40 \mathrm{~cm}$ в глубину, дает возможность ограничивать орошение. Однако для получения высокого урожая продукции хорошего качества почвенная влага должна быть доступной. Нехватка воды снижает урожайность в результате одновременного уменьшения числа листьев на растении и размера листа, а также влияет на качественные признаки, такие, как содержание антиоксидантов.

При выращивании baby leaf применяют спринклерное дождевание: рабочее давление 0,05-0,10 МПа, расход воды 100-200 л/ч, диаметр форсунки 4-6 мм, схема установки $3 \times 3$ м на высоте 2 м во избежание препятствий работе машины. Капельное орошение (1,6-2,0 л/ч) лучше подходит для выращивания на пучковую продукцию. Тем не менее, избыток влаги может привести к тому, что нежные листья будут более подвержены болезням, хотя нехватка воды во время выращивания вызывает задержку в росте растений, при этом листья быстро грубеют. Дефицит воды способствует повышению в листьях фенольных соединений, каротиноидов и антиоксидантной активности. В условиях Италии потребление воды растениями за один полив колеблется от 35 мм осенью до 48 мм в осенне-весеннем цикле с 3-5 поливами. Поливная вода взаимодействует с азотом, влияя на основные характеристики урожайности, и 100\%-ное потребление воды приводит к максимизации товарной урожайности за счет увеличения числа листьев на растении. Эффективность использования воды в зависимости от урожайности варьируется от 33,0 до 37,3 кг/м³ в разных циклах посева, и она на 16\% выше при дозе азота 120 кг/га, чем при использовании половинной дозы [4]. В средней полосе России в зависимости от погодных условий поливают до пяти раз нормой 250 м³/га. Для полива используют катушку для орошения (Ocmis, Италия). 
Засоренность снижает урожай, хотя двурядник тонколистный демонстрирует хорошую конкурентную способность. Применение гербицидов возможно до посева, но нужны и ручные прополки.

Продуктивность колеблется от 1,9 до 8,4 г/растение. Урожай листьев собирают через 20-40 суток после посева или срезки. В средней полосе России возможны только две срезки, т.к. растения быстро переходят к цветению.

Сбор урожая - вручную для пучковой продукции с использованием ножа или серпа; baby leaf убирают комбайном Slide T160 (Hortech, Италия) рано утром, пока не выпала роса. При каждой уборке листья должны быть срезаны на 3-5 см выше семядолей, чтобы избежать повреждения вегетативных почек, что позволяет растениям быстро и обильно отрастать. Убирают листья при достижении длины 10 см. Рыночная доходность варьируется от 0,5 до 1,8 т/ га за каждый цикл выращивания, при этом общая урожайность даже превышает 35 т/га.

Продукцию упаковывают в ящики и сразу же погружают в рефрижератор, охлаждают до $2{ }^{\circ} \mathrm{C}$ в течение получаса для максимального срока хранения. Срок хранения свежей зелени при температуре от 2 до $6{ }^{\circ} \mathrm{C}$ coставляет 6 суток. Контроль качества включает анализ на остаток пестицидов, тяжелые металлы, содержание нитратов и загрязнение микроорганизмами со ссылкой на официальные стандартные пороговые значения.

Микробиологические анализы продукта должны гарантировать отсутствие патогенных бактерий для человека, таких, как Salmonella spp., Listeria monocytogenes, Yersinia enterocolitica и присутствие Staphylococcus aureus, Escherichia coli и других колиформных бактерий в пределах 100 КОЕ/г. Следует уделять больше внимания качеству воды как для орошения, так и для мытья зелени. Санитарную обработку можно проводить путем мойки холодной водой с добавленным дезинфицирующим средством. Хлористые продукты используют широко, но высокий эффект дает обработка молочной кислотой (20 мл/л) и пероксиуксусной кислотой (300 мг/л).

Заключение. При выращивании сеянцев (baby leaf) двурядника тонколистного, убираемых в фазу 2-3 настоящих листьев высотой не более $10 \mathrm{~cm}$, вспашку производить на глубину 30 см, затем - боронование. Формирование гряд шириной 130 см до или одновременно с посевом проводить фрезойгрядоформирователем AF 160 Super (Hortech, Италия), одновременно внося азофоску (16:16:16) из расчета 500 кг/га. Посев семян специализированной сеялкой СM 2000 (Bassi Seminatrici, Италия) в 24 строки. Расстояние между строчками 5 см, между растениями в строчке 5-7 см. Глубина заделки семян 0,2-0,3 см. Норму высева устанавливают из расчета 2,6-3,7 млн шт/га растений. В течение вегетации полив до 5 раз нормой 250 м³/га. Уборку проводить через 30 суток после массовых всходов, вторую срезку - через 10 суток после первой срезки. Сеянцы убирают комбайном Slide T160 (Hortech, Италия) рано утром. Продукцию упаковывать в ящики и сразу же погружать в рефрижератор, охлаждать до $2{ }^{\circ} \mathrm{C}$ в течение получаса.

При выращивании на пучковую продукцию гряды мульчируют черной полиэтиленовой или биоразлагаемой пленкой. Под мульчей капельные трубы размещают в чередующиеся ряды. Выращенную в течение 20-25 суток в кассетах рассаду (15-25 семян на ячейку) высаживают с расстоянием между рядами 10-15 см и между растениями $20 \mathrm{~cm}$, густота стояния растений - от 500 до 1250 шт/м².

\section{Библиографический список}

1.Иванова М.И., Бухаров А.Ф., Литнецкий А.В., Разин А.Ф., Мещерякова Р.А. Принципиальные различия между двурядником тонколистным (Diplotaxis tenuifolia (L.) DC.) и индау посевным (Eruca sativa Mill.) при культивировании в производственных условиях // Аграрный научный журнал. 2018. № 1. С. 14-19.

2.Caruso G., Parrella G., Giorgini M., Nicoletti R. Crop Systems, Quality and Protection of Diplotaxis tenuifolia // Agriculture. 2018. No 8. Pp. 55.

3.Bonasia A., Lazzizera C., Elia A., Conversa G. Nutritional, biophysical and physiological characteristics of wild rocket genotypes as affected by soilless cultivation system, salinity level of nutrient solution and growing period // Front. Plant Sci. 2017. No 8. Pp. 35.

4.Schiattone M.I., Viggiani R., Di Venere D., Sergio L., Cantore V., Todorovic M., Perniola M., Candido V. Impact of irrigation regime and nitrogen rate on yield, quality and water use efficiency of wild rocket under greenhouse conditions // Sci. Hortic. 2018. Vol. 229. Pp. 182-192.

5.Литнецкий А.В., Литнецкая О.И., Иванова М.И. Производство органических сеянцев (baby leaf) двурядника тонколистного // Картофель и овощи. 2016. № 5. C. $25-27$.

6.Conforti F., Perri V., Menichini F., Marrelli M., Uzunov D., Statti G.A., Menichini F. Wild Mediterranean dietary plants as inhibitors of pancreatic lipase // Phytother. Res. 2012. Vol. 26. Pp. 600-604.

7.Kovacic M., Veberic R., Ugrinovic K., Jakše M. Glucosinolate analysis of wild rocket [Diplotaxis tenuifolia (L.) D.C.] from different Slovenian regions cultivated on two growing systems // Eur. J. Hortic. Sci. 2015. Vol. 80. Pp. 199-207.

8.Klein E., Katan J., Gamliel A. Combining residues of herb crops with soil heating for control of soilborne pathogens in a controlled laboratory system // Crop Prot. 2011. Vol. 30. Pp. 368-374.

\section{Об авторах}

Литнецкий Андрей Викторович, соискатель

Иванова Мария Ивановна, доктор с. -х. наук, профессор РАН, зав. лабораторией селекции и семеноводства зеленных культур

E-mail: ivanova170@mail.ru

Кашлева Анна Ивановна, канд. С. х. наук, с.н.с. лаборатории селекции и семеноводства зеленных культур

Балеев Дмитрий Николаевич, канд. с.-х. наук, с.н.с. лаборатории семеноведения

Бухаров Александр Федорович, доктор с. -х. наук, заведующий лабораторией семеноведения

Михайлов Валерий Вячеславович, канд. с.-х. наук, с.н.с. лаборатории селекции и семеноводства зеленных культур

Девочкина Наталия Леонидовна, доктор с. -х. наук, г.н.с. отдела защищенного грунта и грибоводства Всероссийский научно-исследовательский институт овощеводства филиал ФГБНУ «Федеральный научный центр овощеводства»

Aspects of agrotechnology of the perennial wall-rocket in open ground A.V. Litnetskii, applicant

M.I. Ivanova, DSC, professor of RAS, head of laboratory of breeding and seed growing of green crops.

E-mail: ivanova_170@mail.ru

A.l. Kashleva, PhD, senior research fellow, laboratory of breeding and seed growing of green crops

D.N. Baleev, PhD, senior research fellow, laboratory of seed research

A.F. Bukharov, DSc, head of laboratory of seed research

V.V. Mikhailov, PhD, senior research fellow, laboratory of breeding and seed growing of green crops

N.L. Devochkina, DSc, chief research fellow of the department for greenhouse plant crop breeding

All-Russian Research Institute of Vegetable Growing - branch of the FSBSI «Federal Scientific Vegetable Center,

Summary. The agrotechnology of the perennial wall-rocket is presented on the example of LLC Felichita, specializing in its industrial cultivation in the central strip of Russia. In the Moscow region in the open ground seeds are sown from May to mid-August, Tula region - from the end of April to the end of August by an interval of 7 days. The productivity varies from 1.9 to $8.4 \mathrm{~g} / \mathrm{plant}$, the yield is from 0.5 to $1.8 \mathrm{t} / \mathrm{ha}$ for each growing cycle, the total yield exceeds $35 \mathrm{t} / \mathrm{ha}$.

Keywords: Perennial wall-rocket, Diplotaxis tenuifolia (L.) D.C., agrotechnology, yield, open ground. 